\title{
Author's Preface to First Edition (1942)
}

This book had its origins in my lectures on the aggadah and on the Jewish thinkers of the Hellenistic and medieval periods that I gave at the Jewish Theological Seminary in Breslau. I attempted to impress on my students the value of the explanations of the Torah by our predecessors, and my labors were not in vain. My students vied with me in researching this area. While I was discussing Philo's outlook, they shed light on their views concerning Bahya and Maimonides, and together we completed in German a book in which were translated the most important excerpts in which the Jewish philosophers spoke of the reasons for the mitzvot. The book was prepared for publication by the Schocken house in Berlin, but because of the Holocaust that overtook the Jews of Germany it was not published.

When I was privileged to come to Israel and to join the laborers in the Torah that goes forth from Zion, I consulted with Rabbi Y. L. Fishman and the late Dr. Abraham Obadiah about the publication of my research. They informed me that among the educational circles of the religious youth there was occasionally felt the need to survey the explanations of the mitzvot, and they invited me to compose this book for the curricular needs of these educators.

The first purpose of this book is historical. It seeks to describe the answers that were given to our question in ancient times and by the medieval philosophers, to explain them on the basis of the responders' personalities, taking into account the factors of their ages. For the benefit of those who deal in depth with the problem I specified the sources in which the philosophers discussed our question, as well as the modern researches in these topics. One should add to them two articles that I wrote, which have been printed in the meantime and which should appear shortly: one on the collection "Rabbi Saadia Gaon," which is being published by the Mosad Ha-Rav Kook, and one in the journal Kneset (on Rabbi Judah Halevi).

However the purpose of this book is not only historical. I tried to demonstrate that the ideas of our predecessors on the question of religion in general and on the reasons for the mitzvot in particular are based not only on the scientific ideas of their time, but also on the Jewish experience that is common to the ancients and the moderns, and therefore they have 
a value that endures over time. Therefore I emphasized the essential and timeless value of our predecessors' views within the historical narrative and have also devoted a separate chapter to this at the end of the book.

Without sacrificing its scholarly value, I have tried to give the book a popular presentation insofar as the serious theoretical topic discussed in it permits. I have retranslated or explained in contemporary language the primary citations I have brought from these thinkers. I limited myself to what the topic absolutely requires. I have spoken only of the reasons for the mitzvot and have not entered, for example, into their classification or the question of their abrogation. I did not collect all the views scattered in our literature but only the most important answers that were given to our question, and I rested content with a selection of examples that show the method of the thinkers. As for movements outside Judaism that our thinkers opposed or from which they derived benefit, I have treated them only briefly. I have mostly ignored the controversial literature.

The index was prepared by my daughter, Hannah Amreich.

The religions section of the Department of Youth and Pioneering of the World Zionist Organization and the Mossad ha-Rav Kook made possible the publication of this book despite these hard times. In addition I have been assisted by Zvi Harkavy, Isaac Werfel, and Dr. M. A. Kurz in the editing of this book, the first that I have managed to write for the Hebrew reader. They and Mr. Harkavi polished its style and adapted it to the needs of the readers. My friend, Dr. Ephraim Urbach, also assisted me on the first chapters. I express my heartfelt thanks to all of them. 